\title{
“A Right Sort of Man:" Gender, Class Identity, and Social Reform in Late- VICTORIAN BRITAIN
}

The Education Act of 1870 (aka "The Forster Act") marked a watershed in the history of the Victorian state. With this act, England finally joined the other major European states in adopting compulsory elementary schooling for all children. The act divided the country into 2500 school districts, each to have a governing School Board elected by local ratepayers. These boards were authorized to create their own bye-laws regarding school fees and the mechanisms of compulsion in their districts. In a nation where Liberal ideals and the right of individuals to be free from government interference were widely championed, the issue of compulsion was not one that the members of the first School Board for London (LSB) approached lightly. Most of the Board agreed that they should maintain as much continuity as possible between the established traditions of voluntary philanthropy in London's working-class districts and the new, state-sponsored educational reform. To that end, in 1871, the LSB committee tasked with laying a blueprint for enforcing the laws on compulsory education strongly recommended that the Board should hire as School Attendance Officers "women who have had experience in

similar work." ${ }^{1}$ The justification for this recommendation was twofold. First, since these officers would be dealing with mothers on domestic issues the work was "most fitly dealt with by women," and second, they argued that middle-class women with previous experience in domestic reform "will be the least likely to incite resistance" from workingclass mothers. ${ }^{2}$ At the launch of compulsory schooling, the LSB had clearly defined the enforcement of the new regulations as "women's work." 
The initial reaction to the committee's suggestion was mixed. The first School Attendance Officers in London were almost evenly divided between men and women. In 1871, for example, the Lambeth Division of the LSB hired 4 women and 4 men as Visitors; the former were paid $£ 50$ per annum, the latter, $£ 80 .^{3}$ From an initial gender parity in 1871-2, moreover, the numbers of women serving as London School Attendance Officers declined rapidly. In May of 1872, more than half of the London Visitors (25 of 47) were women, but by 1874 , two of the largest School Board Divisions in London had no female Visitors at all. ${ }^{4}$ The number of female SAOs in the metropolis as a whole dropped rapidly over the course of the decade, and this pattern would be repeated across Britain. $^{5}$

The exclusion of women from the profession of School Attendance Officer (a.k.a. School Board Visitor) complicates the picture of late-Victorian social policy as it has been drawn by recent historians. Seth Koven and Sonya Michel have both emphasized how the development of the welfare state and, in particular, state policy on children's welfare, were arenas where women played an increasingly prominent role. ${ }^{6}$ The masculinization of the SAOs profession ran contrary to the general trend of women's employment in the field of education and their involvement, albeit largely at a local level, in the Victorian state. Previous historians have pointed to the expansion of the English government - and the expansion of the state educational apparatus in particular - during the Victorian era as a phenomenon that opened the doors of opportunity (however tentative) for women's employment as "professionals." described the opening up of such opportunities, however, have also shown how women were often excluded from positions of authority within the state educational system. ${ }^{8}$ 
The primary focus, though, has often been on the exclusion of women at the higher levels of educational organization, such as School Board Members and Her Majesty's Inspectors of schools. The transformation of school attendance work into an almost exclusively male preserve demonstrates how women could also be systematically excluded from even the lowest levels of state education system. Since such a career could have been open to women of relatively modest social, economic, and educational backgrounds, this exclusion was highly significant. Not every woman could aspire to be a School Board Member or an HMI, but the formal qualifications for the position of School Attendance officer were relatively modest. ${ }^{9}$ The success of male SAOs and their immediate superiors, the District Superintendents, in excluding women from the profession was dependant upon their masculine appropriation of domestic morality and their redefinition of social reform from a "voluntary," "personal" activity appropriate for women to a "professional," "bureaucratic" endeavor for which only men were suitable. This process involved the disempowerment of Victorian women in two capacities: first, it entailed the exclusion of middle-class women from this arena of organized state reform and second, the blaming of working-class mothers for the "moral decline" of workingclass homes that made such reforms necessary. ${ }^{10}$ To put it simply, according to local administrators and the agents who executed policy, women were the root cause of social ills that they themselves were inherently incapable of ameliorating.

In addition to highlighting how the expansion of the Victorian state, even as it provided new opportunities for women, helped institutionalize their exclusion from "professional" roles, the efforts by SAOs and their superiors to "masculinize" their profession provide valuable insights into the relationship between gender, class, and 
morality and into the nature of lower-middle-class identity in this period. If the lower middle class remains an overlooked segment of Victorian society, the gender history of this elusive segment of society is even less well understood. ${ }^{11}$ Recently, historians have begun to recognize the vital role that masculinity played in the lives of lower-middleclass men. ${ }^{12}$ Among School Attendance Officers, who were challenged to work in what the LSB initially conceived to be a feminized sphere of activity, issues of gender roles and identity took on considerable urgency.

But to place the SAOs firmly in the "lower middle class" is itself problematic, both because the cohort was not well-defined and because the SAOs' salary, social background, and work environment all existed in the liminal space between the working and middle classes. The men who became SAOs were more likely to be drawn from the ranks of policemen, soldiers, and artisans than they were from the ranks of Victorian clerks. If their social origins were most commonly working-class, however, the identity they built for themselves, which focused on morality, education, professional association, and the drawing of a strong distinction between themselves and the ranks of laborers, was closer to a middle-class ideal. Regardless of their often modest social origins, it is clear that the SAOs aspired to be recognized as part of the white-collar workforce. The implementation of the compulsory attendance laws, according to the journal of their national association, was "not the work of artizans, but men of education." 13 SAOs" efforts to define their work as being "professional" illuminated the fluidity of class and gender identities and their relationship to morality and domesticity in Victorian England.

The campaign waged by SAOs and their Superintendents to establish the former's work as an exclusively male preserve also highlights some of the essential tensions 
operating within late-Victorian social reform. Among the most important are the construction of a firm distinction between compulsory state reform and voluntary reform or charity, and debates over the efficacy of coercion versus persuasive tactics. Underlying these debates is the more fundamental contrast between the elevation of a "masculine" approach to reform, which stressed bureaucratic tactics, legal methods, professionalism, and an assertive moral authority on the one hand and the concurrent deprecation of a "feminine" approach that advocated personal contact with the working class and sought to bridge the growing chasm between classes in Victorian society on the other. In these debates, men had a considerable advantage because the structure of the Victorian state education system insured that their voices would dominate most public discussions and policy decisions. ${ }^{14}$

This did not mean, however, that the masculine approach to social reform would be unanimously championed. Male state agents ultimately found that the methods developed by voluntary female reformers were often more practical and, equally important, more supportive of their attempts to fashion a positive professional image for themselves than the more aggressive, impersonal, masculine approach championed by their superiors were. For the SAOs, the dilemma of how to work in a traditionally feminine sphere while establishing a masculine identity set the context for their efforts to define themselves as professionals, to work effectively, and to gain the respect of those both above and below them in the social hierarchy. It is only against the backdrop of these tensions - between volunteerism and professionalism, persuasive tactics and coercive tactics, and, lastly between self-consciously "feminine" and "masculine" models 
of social reform - that the significance of the School Attendance Officers and their role in the late-Victorian state becomes clear.

$$
* * *
$$

When interviewed by LSB members in 1874, the District Superintendents of Visitors gave a variety of arguments for why, contrary to the Board's initial recommendations, women did not make suitable SAOs. Most of their objections focused on the two aspects of attendance work that differentiated it most strongly from private, volunteer social reform - taking an informal census of all children in a neighborhood ("scheduling") and the prosecution of school attendance cases in the local courts. ${ }^{15}$ One Superintendent said simply that "cases sometimes occur which they [female visitors] cannot deal with, and hence they need the assistance of male Visitors."16 The most revealing response came from the Superintendent for the Marylebone Division, who wrote that he "had six [female visitors] to look after. (a) they are not physically capable of the really hard work. (b) they do not carry the same weight or authority as a right sort of man. (c) they are given to too much talk - too fond of argument. (d) I have reason to think they have, now and then, 'pet aversions.' (e) They do not look well as 'Officers of the Board' in Police Courts, and frequently prove too much." ${ }^{17}$ In effect, the Marylebone Superintendent had taken the very characteristics that, according to the LSB's initial findings, had made women seem so suitable as attendance officers and portrayed them instead as liabilities. In particular, their proclivity for conversing with their subjects and their unobtrusive bearing were held up as disadvantages in the execution of the attendance laws. Women were physically weak and emotionally fickle ('pet aversions'); their tendency to talk to their charges made them inefficient, and they were wholly 
unsuitable as public representatives of the Board in the formal legal milieu of the police courts.

It is tempting to attribute the contrasting views on women's suitability as School Attendance Officers to the gender make-up of the London state education apparatus. The LSB had a small but vocal female contingent - Emilie Davies and Elizabeth Garrett, for example, were both elected to the first LSB in $1870 .{ }^{18}$ The District Superintendents, on the other hand, were an exclusively male cohort. Such obvious contrasts, however, mask the broader differences between the attendance work and the voluntary reform that had preceded it. These differences derived from two main factors: the contrast between voluntary and state-sponsored reform and the SAOs relative social position vis-à-vis the working class. Seth Koven and Martha Vicinus have observed that the transfer of social reform projects from voluntary to state-run enterprises, starting in the 1840s, was accompanied by a lessening of female independence and authority and an increasing encroachment of male management and policymaking. ${ }^{19}$ Although women could be, and were, elected to the School Boards, the majority of their members remained men, as did the officials of the bureaucratic hierarchy that extended from the boards up to the Education Department, which ultimately oversaw the entire state education system. At the level immediately above the SAOs, there was not a single female District Superintendent in all of London. Since the Superintendents were responsible for monitoring the performance of the SAOs and ultimately for recommending their continued employment or their release from service, their opinions carried great weight in staffing decisions. The view of (mostly male) state officials on reform, moreover, was often at odds with the approach that volunteer woman had adopted in their reform efforts. 
Women's involvement in voluntary reform was originally an extension of their roles in the domestic sphere. Voluntary social reform projects directed at "domestic" issues such as child welfare and health allowed middle-class women to stake a claim in a public sphere where Victorian discourse otherwise gave men preeminence. ${ }^{20}$ By the time such enterprises began to come under state purview in the mid-nineteenth century, middleclass women had already established considerable authority there, and could thus contribute to the effort without transgressing gender expectations. ${ }^{21}$

Even when working in the public sphere of reform, however, most middle-class Victorian women remained committed to the supposedly nurturing qualities of feminine character. As the state became increasingly involved in these projects, women continued to advocate an approach that stressed sympathy, compassion, and personal contact, what Koven and Michel have described as a "maternalist" or "mothering" state. ${ }^{22}$ But in their efforts, they often found themselves at odds with the more bureaucratic, impersonal, and coercive approach advocated by male state agents. ${ }^{23}$ Sydney Turner, the first of Her Majesty's Inspectors of reformatory schools, contrasted the "sentimentality," "petting" and "indulgence" of the feminine approach to reform with the more effective "manly, straightforward, and strengthening tone," of the masculine approach. ${ }^{24}$

When Superintendents complained that women SAOs were "too fond of argument" and did not carry the same "weight and authority" as a man, they were mirroring the contrasts between masculine and feminine methods of reform articulated by their superiors and arguing that the latter was ineffective in school attendance work. Superintendents consistently argued that what they saw as the key aspects of Visitors' work, "scheduling" and the prosecution of the attendance laws in the local courts, were 
the two duties women were least capable of performing. ${ }^{25}$ A good SAO, according to this view, would carry out his duties using a masculine, impersonal, bureaucratic approach that depended upon his official authority, the objective evidence of his attendance records, and legal coercion through the courts, rather than a feminine approach that revolved around personal contact and extended discussions with parents.

The Superintendents' arguments on the role of Visitors as legal representatives, the necessity of coercive tactics, and the inadvisability of extended interaction between state agents and working-class men and women, however, were not wholly replicated in the attitudes of the Visitors themselves. The efficacy of the methods developed earlier within the context of volunteer female philanthropy became clear to the London Visitors over time. When the London Visitors were interviewed by the LSB in 1891, they championed precisely those qualities and approaches that the Superintendents had criticized fifteen years earlier. Persuasion, communication, and an intimate knowledge of the character and circumstances of working-class parents, they argued, were the keys to success. ${ }^{26}$ Indeed, some statements by Visitors echoed the rejection of bureaucratic, impersonal methods articulated earlier by middle-class women volunteers. In an article printed in the inaugural edition of the Visitors' professional journal, The School Attendance Officers' Gazette (later renamed The School Attendance Gazette), one author wrote that the profession of SAO "has attracted into its ranks the men who, not content with performing their duties like machines, desire to work out [of] an ideal."27 Part of the motivation for such statements, however, was Visitors' assumption that by emphasizing the moral dimensions of their work over its bureaucratic aspects, they would win greater 
respect, status, and remuneration from both their immediate superiors and the general public. $^{28}$

In contrast to Superintendents' emphasis on the importance of Visitors' roles as representatives of the state in local courts, many SAOs stressed that legal coercion should be avoided whenever possible and used only when the established approach of "moral persuasion" had failed. ${ }^{29}$ SAOs and Superintendents also differed in their general attitudes towards women in the courts. The former insisted that, in order to be effective, the laws on school attendance should hold mothers as well as fathers accountable for a child's school attendance. Superintendents, on the other hand, were consistent in their opposition to the presence of women in the courts, applying this view to both female SAOs and working-class mothers. Rather than insisting that the law be changed to hold mothers legally accountable, the Superintendents argued that the 1873 Act dealing with summary prosecution should be altered so that the accused (i.e. the father) could not send his wife to answer the charges but had to appear in person and thus, upon conviction, promptly face any sentence handed down.

Despite Superintendents' assertions to the contrary, there were considerable parallels between the "feminine" approach of middle-class volunteers and how male SAOs engaged their work, and thus there seemed to have been no practical reason why women could not perform well as school attendance officers. In several important ways, moreover, both the approach and motivations of SAOs were mirrors of their middle-class, female predecessors in volunteer and "amateur" philanthropy. The "moralized" approach to reforming the working class, for example, was a prominent shared theme. ${ }^{30}$ In particular, SAOs and the host of female District Nurses, Charity Organization Society 
agents and settlement house workers all shared a deep commitment to sorting the "deserving" from the "undeserving" in their work. ${ }^{31}$ The opposition to alcohol was another common principle. ${ }^{32}$ Likewise, both male SAOs and female social reformers were acutely aware of ethnicity and the obstacles that the cultural distance between themselves and their charges could present in their efforts. ${ }^{33}$ Above all, SAOs and female social reformers shared an unwavering confidence in the rightness of their cause and in the necessity of their presence as a positive moral influence in working-class neighborhoods.

The Visitors' emphasis on morality was prominently demonstrated in their detailed descriptions of their districts, which were collected by Charles Booth's assistants in 1886-1887 as part of the research for Life and Labour of the People of London. Like their middle-class, female, volunteer predecessors, Visitors were keen to sort the "deserving" or "respectable" from the "undeserving." 34 For "deserving" parents, the Visitors might lend a sympathetic ear, describe them favorably in their reports, or even draw the attention of charities to their plight. The "undeserving," however, were vilified in the Visitors reports and, when appropriate, they would recommend prosecution according to the School Attendance Bye-Laws. It is ironic that Booth used the information provided by the Visitors, men who frequently attributed poverty to moral causes and drunkenness, as evidence that poverty was largely the result of a labor market over which working-class Londoners had no control. ${ }^{35}$

Reflecting shifts in late-Victorian discourse on class and morality, the Visitors did not, as a rule, always argue that poverty was in and of itself a sign of moral degradation. In their eyes, a street, household, or individual could be poor but respectable. ${ }^{36}$ They 
were more concerned with the circumstances that led to such poverty, and made their judgments accordingly. To differentiate between the "respectable," and the "rough," the Visitors employed a series of commonly-understood signs and terms. Amongst the most frequently-used indicators of immorality were filth, poor physical condition of the houses, children in the streets, violence, and drunkenness. ${ }^{37}$ The term "respectable," along with "decent" and "hard-working” were ubiquitous in Visitors' descriptions of parents who conformed to their moral standards. In contrast, they classified those who violated the moral parameters by which the Visitors' evaluated their subjects they classified as "dirty," a "bad lot," a "filthy lot," or, perhaps the most common and damning, "poor . . own acct.[on own account]." 38 Using physical metaphors to indicate moral failings was common amongst those who worked in the state educational system. ${ }^{39}$ The outwardly-visible filth and disorder mirrored an inner moral corruption, and cleanliness was likewise an indicator of respectability, hence the emphasis in girls' education on housekeeping and laundry work. ${ }^{40}$

Besides drawing on a common terminology of respectability to describe the moral status of working-class streets and households, SAOs and middle-class female volunteers also shared similar motivations, in part, for engaging in their work. The desire to legitimate their participation in the broader sphere of Victorian public life was a common cause for both groups. Likewise, the "heightened sense of individual worth" identified by Seth Koven as an instrumental factor in middle-class women's volunteer work was also part of the Visitors' motivations. ${ }^{41}$ The disparity in gender and social position, however, between the men who became SAOs and the middle-class women who worked in private philanthropy, prompted significant differences in how the two groups engaged 
London's working class. The confidence with which middle-class women approached the reform of working-class households, however, was dependant upon their assumed moral superiority and alleged expertise in domestic affairs. ${ }^{42}$ Beyond those assumptions, most middle-class reformers felt that social contact alone between the middle class and the working class would have a positive effect on the latter. ${ }^{43}$ This assumption was a natural outgrowth of Victorian discourses on the causes of poverty and immorality, which held the social and geographic alienation of the working class from the middle and upper classes was a chief cause of these ills. ${ }^{44}$

The differences between the SAO's approach to reform and that of their female, middle-class predecessors lay not in a rejection of personal contact with the working class, but rather in the relative moral and social position from which, ideally, that contact would be made. The goal of many middle-class female reformers was to bridge the gap between themselves and their working-class subjects, and by that proximity morally uplift the latter. But the SAOs, in contrast, went to great lengths to establish and maintain, both in action and discourse, a social distance from working-class parents. ${ }^{45}$ Unlike their female, middle-class counterparts, furthermore, the SAOs never claimed to be advocates for the poor, nor did they seek to find common ground with them in their work. For almost every positive capacity that Visitors ascribed to themselves - diligence, morality, sobriety, enthusiasm for education, compassion towards children - they argued that the converse was prevalent among working-class parents.

The effect that relative class position had on the dynamics of social reform was highlighted in one of the SAOs' most significant contributions to the late-Victorian discourse on class and poverty, which was their role in Charles Booth's survey of the 
London poor. The information gained from the Visitors' notebooks and interviews with the agents themselves formed the centerpiece of Booth's study. ${ }^{46}$ Just as the Visitors used their experiences among the poor as a touchstone for the establishment of their own moral position, so too did Booth use their information as support for his own conclusions about the nature of poverty, its causes, and possible ameliorations. Like those of the Visitors, Booth's observations and conclusions were drawn in the context of his own efforts to identify his role in the reform project and his social position vis-à-vis workingclass Londoners. Booth claimed that he was an empiricist and that he was seeking to avoid the dramatization of poor people's lives that was common in journalistic accounts of the subject. ${ }^{47}$ It proved impossible, however, for Booth to rely on a source that was itself so heavily laden with moralized language without replicating it himself. Consequently, there were significant parallels in how both Booth and the Visitors described working-class households. In his writings, Booth deployed the same discourse that the Visitors used to distinguish the "rough" from the "respectable," house by house and street by street.

Like female middle-class volunteers, and in contrast to the SAOs, however, Booth ultimately claimed a personal connection to the poor, and sought an intimacy with them that the SAOs tended to eschew. Whereas the Visitors used the working class as a moral foil against which they could define themselves, Booth, operating from a more secure position in the social hierarchy, often expressed admiration for the qualities he found in his subjects. Some of the starkest contrasts were apparent in their respective descriptions of parenting. The SAOs were almost unanimously critical of working-class childrearing and this particular failing served as the central justification for their enforcement work. 
Good parents, their reasoning held, would send their children to school regularly, and the ubiquity of poor school attendance was thus a testimony to the failings of working-class parenting. Booth wrote, conversely, that "the simple natural lives of working-class people tend to their own children's happiness more than the artificial complicated existence of the rich." ${ }^{48}$ He even claimed that the moral status of the parents did not necessarily translate into poor childrearing, an argument that directly contradicted the claims of the SAOs. ${ }^{49}$ Booth sought connection where the SAOs sought distance, and his sympathetic tone and embracement of the moral complexities of working-class life stood in contrast to the moral absolutes promulgated by the Visitors. ${ }^{50}$

Ultimately, Booth drew different conclusions from the Visitors about the cause and character of poverty in London. The latter remained wedded to the mid-Victorian attitude that poverty was often the result of moral failings such as laziness or drunkenness, hence their constant, damning description of innumerable households as "poor ... [through] own account." Booth, in contrast, argued that poverty was caused primarily by lack of economic opportunity. ${ }^{51}$ On the ameliorative potential of compulsory education, however, the Visitors and Booth were in agreement. The positive results of the policy, according to Booth, lay not in the transformation of working-class boys and girls from workers into scholars. ${ }^{52}$ He claimed that the successes of compulsory education lay rather in the moral education of working-class children and their instruction in the practices that made one "respectable," arguing that through these lessons, the working class had been given the means to morally uplift themselves. These were all goals that had been at the center of the arguments for compulsory education at its inception and remained prominent in the vision of both Visitors and their 
Superintendents. "Obedience to discipline and rules of proper behavior have been inculcated," Booth wrote in praise of compulsory education, "habits of order and cleanliness have been acquired; and from these habits self-respect arises. ${ }^{~} 53$

Charles Booth was not the only authority in late-Victorian social reform who found himself at odds with the Visitors' claims to moral expertise even as he expressed his appreciation for their dedication. In their attempts to forge a masculine, professional identity for themselves in the context of social reform and the Victorian state, SAOs also encountered considerable resistance from within the bureaucracy that managed their efforts as well. When asked by the London School Board to explain the deficiencies in school attendance in his Division, the Superintendent of West Lambeth, for example, claimed that "the class of Visitors might be improved as some of the present staff were not men to carry the weight and respect they should. The scale of salary should be increased, as the present remuneration would hardly secure a better class of men." ${ }^{\prime 54}$ Male Visitors were drawn primarily from the ranks of former soldiers, policemen, and artisans. ${ }^{55}$ Men like Elias Eisenstadt, a poor Polish Jewish immigrant who had once made a living by selling scrounged goods from a hand cart, or David Parry, a former coal miner, could hardly be recognized by their superiors as being morally qualified on account of their class position. ${ }^{56}$ Nor could Daniel Gerrard, the vice-president of the Visitors' national organization, claim to possess the same domestic knowledge as a middle-class female volunteer. His "domestic experience" consisted of his upbringing in an orphanage and his work as a chimney sweep. ${ }^{57}$ 
In response to the doubts expressed about their fitness for duty, Visitors laid claim to a moral authority founded upon masculinity, rather than upon class position. The foil in this effort was working-class mothers, whom the Visitors portrayed as ignorant, neglectful, and selfish. According to Visitors, the moral decline of the working-class home was attributable specifically to the failures of working-class female domesticity. This focus on mother's habits and behavior was yet another aspect of the Visitors' work inherited from the tradition of volunteer female philanthropy. ${ }^{58}$ With working-class fathers' authority in the home circumscribed by long working hours and an alleged ignorance of domestic affairs, only the intervention of male domestic authority in the form of the Visitors could resuscitate the degraded moral atmosphere of the household, the Visitors claimed. The pages of the Gazette were filled with stories, cartoons, and mock editorials that ridiculed working-class mothers, portraying them as greedy, deceptive women who had no desire to see their children educated and who treated the Visitors' efforts with scorn and contempt [see Fig. 1]. One constant criticism leveled by the Visitors was that parents, and in particular mothers, were far more concerned with the wages their children could bring in than they were with securing for them the long-term benefits of education. Witness the fictional conversation reported by one Visitor in the very first issue of the Gazette:

Officer, scheduling, "How old is John?"

Mother, "Well I don't exactly know."

Officer, "But surely you have some idea."

Mother, "Well the nearest I can tell you is, that he was twelve [i.e. of working age] last fruitin' time." 59

Fig. 1. "The Challenge," The School Attendance Gazette, August 1902. 
As an effective counter to the degenerate state of working-class women's domesticity, the Visitors depicted themselves as paragons of masculine moral virtue, worthy - or even superior - successors to the middle-class volunteers who, in previous decades, had reformed their charges through the moral authority granted by their class position and the domestic knowledge associated with their gender. Surrounded by the moral degradation of urban poverty, the Visitors claimed to maintain their authority, through their adherence to a strict and unforgiving code of masculine moral conduct. As one author instructed his colleagues:

Be free from the taint of intoxicating liquors, tobacco, and snuff.

Educate yourself in the work; master its details and be watchful of opportunities. Be neat in appearance, punctual in attendance, zealous in your duty.

Be energetic and ambitious in your efforts; work with your head as well as hands. Be honest in your intentions; kind, cheerful, courteous, and prudent in your dealings with teachers, parents, and children.

Be frank when expedient, and reticent when essential. ${ }^{60}$

"Charged with the special duty of invading the vilest haunts of debauchery, immorality, and crime," another author wrote, it was the Visitors' dedication to duty and his moral rectitude in the face of thorough degredation that allowed him to "fairly claim to be the greatest social reformer that has appeared in the present age." 61

Not surprisingly, the idealized image of the Visitor laid out in the pages of the Gazette possessed the exact qualities that the immoral parents they described had lacked. Whereas the parents the Visitors wrote about for the Booth project were often "dirty," the Visitors were "neat;" where they were "drunk," Visitors were "free from the taint of intoxicating liquors;" and where the parents were "lazy" or "poor on own account," Visitors were "energetic," "ambitious," and "punctual." Unlike the middle-class observers who deployed these tropes, however, Visitors argued that these characteristics 
of "respectability" were essentially male. Or, to be exact, even if their female counterparts in the Visiting endeavor (professional or voluntary) possessed them, theirs was a passive morality that was ineffectual outside the confines of the home, hence the statement by the Marylebone Superintendent that women lacked both the physical capacity and, more importantly, the "weight" and "authority" necessary for the hazardous task of reforming the working class. ${ }^{62}$

The most conspicuous presentation of SAOs' masculine morality could be found in the biographical sketches published in the School Attendance Gazette. These biographies celebrated the moral virtues of men who had, through diligence and virtue, pulled themselves up from modest or even impoverished origins. The authors of the articles presented the lives of the SAOs as struggles against adversity, struggles that had proven their dedication to education and their worthiness to vanguard the moral uplifting of the working class. The image of the "self-made" man who had struggled from modest beginnings to achieve a position of respect and even admiration in society was an essential element of lower middle-class identity - an identity that the SAOs were selfconsciously seeking to adopt - in Victorian England. ${ }^{63}$ The biographers and eulogists of the Gazette ascribed an almost mythic power to personal ambition and perseverance. Even the most impoverished background and tragic family circumstances, the stories in the Gazette suggested, could be overcome through dedication, ingenuity, and character.

Among the most prominent of the SAOs profiled in the Gazette was Daniel H. Gerrard, the Vice-President of the Schoool Attendance Officer's National Association (SAONA). Although Gerrard eventually settled in Glasgow, he had been born in Norfolk in 1849. After losing his father, a policeman, during a riot, Gerrard became a ward of the 
state. ${ }^{64}$ He spent the next five years in an orphan's home in Norfolk, where he received only the most basic academic education. By the time Gerrard left the orphanage at the age of eight, he had "barely [mastered] the alphabet and words of one and two syllables." Gerrard was given over by the orphanage to a firm of chimney sweepers, whose owners had chosen him from amongst the other boys, "as being most suitable on account of his slender build." He remained with this firm until the age of eighteen, when "his desire to make headway in life" prompted him to enlist in the army. After mustering out of the army, where he completed his education of his own volition at the regimental school, Gerrard accepted a position as a school attendance officer in 1876. Summarizing the life, thus far, of Daniel Gerrard, the author of the biography wrote, "his life is a record of triumphs over difficulties. To start under such unfortunate circumstances, and yet achieve a position of honor and influence, to have earned the respect and esteem of those above and below him in station, is a record his colleagues are proud of."

At first, Gerrard, an orphaned chimney sweeper who was nearly illiterate as a child, seems to have had little in common with Thomas Salter, an SAO from Bristol whose biography appeared in the December 1902 issue of the Gazette. Salter had "commenced to read the Bible at a very early age," and was described by the biographer as a "scholar." ${ }^{65}$ He had attended a voluntary elementary school and later a boarding school near Kingswood. Upon closer examination, however, we learn that Salter's father, like Gerrard's, was from a modest social background - Salter's father was a builder. Up until the time he became an SAO, Salter had worked in his father's trade as a carpenter. The author also tells us that Salter was connected with "various clubs, societies, and associations." Indeed, it was his "advocation of the "rights and just 
demands of his colleagues" as a member of the Amalgamated Society of Carpenters and Joiners, an organization that Salter had joined immediately after its inauguration, that first brought him to the attention of the chairman of the Bristol School Board. ${ }^{66}$ In July of 1872, the Bristol Board “" induced [Salter] to become a School Attendance Officer.”

The men who became SAOs came from a broad range of socioeconomic backgrounds, from the poorest of laborers to white-collar clerical workers. David Parry, of the Dudley School Board, started work in the coal mines of his home town at the age of eight. ${ }^{67}$ William Spencley, by contrast, was employed as a clerk before he began work for the Birmingham School Board. ${ }^{68}$ T.W. Taylor served as an assistant master at schools in Leeds, Exeter, and Bristol, while Elias Eisenstadt, a poor Polish immigrant, made his first pence in his new country by "acquiring various saleable articles which he carried around for sale in the city of Hull and its neighbourhood." ${ }^{\circ 9}$ Although military service, as David Rubinstein has suggested, was common among SAOs, in the men profiled by the Gazette, an artisanal background was also common. ${ }^{70}$ If there was a universal character to the employment of the men who became SAOs, it was only that they all came to the position not as their first occupation, but as the last stage in what was often an extensive employment history. Stephen York, for example, had worked as a plasterer, a boot maker, and an auctioneer's clerk before becoming a SAO. ${ }^{71}$

Although their clerical duties required SAOs, especially those working in urban environments, to be literate and possess a solid grasp of basic mathematics, the profiles in the Gazette often described men whose initial experience of formal schooling had been quite limited. The early education of John Frost, like Daniel Gerrard's, had been brief and difficult. "His father dying while he was quite young," his eulogy tells us, "he 
received little education; having to leave school at a very early age and assist in supporting his widowed mother and young family." ${ }^{, 72}$ Frost was determined, however, not to remain illiterate. "He has stated," the biographer recorded, "that he never learnt to read or write until he was seventeen years of age, when he attended the Sunday School of the New Church Society (Swedenborgonian), Bath, for the express purpose of improving his education." The obituary emphasized, furthermore, that Frost's interest in developing his education continued throughout his later life. The author of the piece related how, within a few days of beginning his work as an SAO, Frost observed a colleague using shorthand and immediately set about to learn the skill himself. "He commenced, at the age of 37 with all the zeal so characteristic of him, to acquire the phonographic art; and rarely ... did he miss having his one and a half hours of study of this science, until he had acquired the learner's, reporter's, and teacher's certificates, after which for a long time he taught shorthand pupils with success." ${ }^{.73}$

The "struggle against adversity," which biographers described as being commonplace in the lives of the men who eventually became SAOs, could take many forms, but none was more exemplary than that of Elias Eisenstadt. His biographical sketch took the form of an allegorical pilgrimage from poverty and apostasy to faith and professional renown. As a young Jew, Eisenstadt arrived in Hull in 1865, "friendless, with slender means, ignorant of a word of English, and only 21 years of age."’74 Eisenstadt's troubles, the Gazette writes, were compounded by a somewhat precipitous religious conversion. After reading a Christian pamphlet printed in Hebrew, "he declared himself a Christian, and from that time became ostracised by his own nationality, thus becoming in a double sense a stranger in a strange land." ${ }^{, 75}$ While eking out a living as a 
door-to-door hawker, selling whatever he could scrounge, Eisenstadt was counseled by a kindly missionary to go to London "where he would find a refuge and employment for Converted Jews." The sense that one is reading an allegory as much as a biography is compounded when one reads that "his [Eisenstadt's] stock of money was so slender that his only means of making the journey from Hull to London was on foot.” Eisenstadt arrived safely in London, thanks to the hospitality of those he met on the road, and secured work as a bookbinder. After writing a book called "The Bible in the Workshop," which was published in 1863 (a scant seven years after his arrival in Hull as a penniless Polish immigrant), Eisenstadt left his trade to become a City Missionary and was appointed as an SAO later that year. He went on to become the president of the London branch of the SAONA in 1891. The ultimate recognition of Eisenstadt's achievements, came in 1892, when the U.S. Department of the Interior, “"in consideration of his distinguished services in the field of education," invited him to attend the World's Congress on Education in Chicago as the Honorary Vice President of the Department Congress of Elementary Education.

It is hardly surprising that a journal devoted to the work of School Attendance Officers should emphasize the commitment of its subscribers to education. Some aspects of the Gazette's focus on education, however, are particularly worth noting. The biographical sketches of the SAOs emphasized that these men had educated themselves voluntarily and often in the face of considerable adversity. The Gazette did not typically present the profiles of men who had enjoyed the economic luxury of pursuing full-time education beyond the elementary level, but rather wrote often of individuals who had worked industriously at their jobs and, at the same time, continued their education 
whenever the opportunity arose. The biography of Stephen York typified this image of the hard-working man who was devoted to his own education. As the Gazette wrote, "not content with merely taking steps to earn his daily bread, Mr. York during these years took advantage of the facilities offered by science and art classes and University Extension Lectures to add to his knowledge of useful arts and sciences."76

The overall impression conveyed by the biographies found in the Gazette was that the School Attendance Officers were all men for whom, against considerable odds, education had been an effective means for self-improvement. In particular, their stories emphasized the power of education to overcome the economic and social disadvantages faced by many of these men in their youth. This emphasis resonated with the common tendency among policymakers, school officials, and working-class parents to link the issues of compulsory school attendance with that of children's labor. By repeatedly demonstrating the redemptive power of education in even the most desperate economic circumstances, the editors of the Gazette were implicitly arguing that education was not a hindrance to economic self-improvement but, on the contrary, a powerful encouragement to it. The biographical sketches found in the Gazette served to counter the argument, common among those opposed to compulsion, that labor was more necessary and beneficial for working-class children than education was. They demonstrated the longterm practical benefits of education, regardless of the sacrifice required, for even the poorest of Britain's children.

The emphasis on the long-term benefits of education, as exemplified by the SAOs profiled in the Gazette, also served as a moral defense against those who criticized the attendance officers for their interference in private life and their willing participation in a 
system of state coercion. The biographical sketches in the Gazette justified the SAOs' work based on a weighing of long-term economic benefit over short-term need. As with the female volunteers that preceded them in the work of "visiting" working-class homes, the SAOs defended their intrusion into the home and their violation of the cherished principles of "English liberty" with the argument that such measures were necessary for the ultimate good of the family. ${ }^{77}$

Despite their concerted campaign of self-validation, however, the moral and social status of SAOs remained tenuous in the eyes of many, and they were harshly criticized by school teachers, middle-class social reformers, and working-class parents alike. As the lowest rung in the hierarchy of the state education system they were often made the scapegoats by those who portrayed state social reform as a "tyranny" deeply antithetical to English ideals. ${ }^{78}$ Lambasting the work of the Visitors, one such critic suggested that "the attendance prowlers should be stuffed down a sewer."79 Visitors responded with their own criticisms of teachers and Poor Law guardians - as with their working-class subjects, the most common tactic was to assume the moral high ground, arguing that the Visitors themselves were the only group truly concerned with the welfare of their charges. One article in the Gazette publicly accused teachers of being immoral, "mercenary," and unconcerned with the wellbeing of the children in their charge. ${ }^{80}$ "There are many teachers," the Visitor claimed, "who fail to take the least interest, other than a pecuniary one, in their calling. When attendance flagged in such circumstances, the author wrote, these Head Teachers, would "straightaway proceed to blacken the reputation of the attendance officer, for they seem to imagine that the fault lies with the unlucky official, and that if they can get him removed another place, they may be more 
fortunate in turning his successor into a very useful lacquey [sic]." Another Visitor used the Booth interviews as an opportunity to broadcast his criticism of the Poor Law Guardians and their workhouse system. Mr. Bruce, a Shoreditch Visitor, described the Guardians as bullies who threatened poor widows into giving up their homes and entering the workhouse with their families. ${ }^{81}$ According to him, the relieving officers were taking the easy way out: rather than using "moral suasion" to reform the working-class home, as many Visitors advocated, they simply dismantled it, thus burdening the ratepayers with permanent charity cases and dooming the families themselves to irrecoverable penury.

Meeting resistance to their methods, criticism of their work, and doubts about their authority from many directions, SAOs also sought other ways to successfully "masculinize" their profession. One very direct tactic was to deny women SAOs access to the resources and networking provided by their professional organization, the School Attendance Officers National Association, founded in 1884. It is not clear whether women were denied entrance altogether or accepted but not allowed to participate in Association events such as the numerous regional conferences hosted throughout the $1880 \mathrm{~s}$ and 1890s. What is apparent is that the voice of female attendance officers was entirely absent from the Gazette, the official paper of the Association. Not a single article authored by a woman ever appeared prominently in the journal. Women's only roles in its pages were as mothers of schoolchildren and as the objects of satire, most commonly as the central figures in the numerous cartoons lampooning the ignorance, obstinacy, or outright hostility of working-class mothers. The only other female voice in the Gazette was the fictional author (in fact a man) of the regular column "Sum Edjukashonal Topix," which, with its atrocious misspellings and comically obtuse 
reasoning, was itself a vehicle for further ridiculing the women depicted in the Gazette's cartoons.

Another tactic employed frequently by the Visitors to masculinize the image of their profession was to portray their work as being fraught with physical danger. In the initial decade after the passing of the Education Act of 1870, when compulsory education was a new and unwelcome phenomenon in working-class neighborhoods, one memorialist of the London School Board claimed that both verbal abuse and physical assaults were common, albeit the former much more so than the latter. ${ }^{82}$ Although the School Attendance Gazette reported only about a dozen assaults upon Visitors - fully half of which occurred in London - between April 1900 and September 1903, the editors portrayed such violence as ubiquitous. Dramatic stories of abuse, threats, and assaults upon Visitors appeared in nearly every issue. A 1903 excerpt from the Leeds Daily News reported that "the public ... poke fun or throw flat irons at them. The baiting of school attendance officers has been reduced to a fine art in some of the slum districts, and the perils of a football referee are mild to the risks he has run." 83 Taken altogether, the periodicals covering the issue indicated that abuse was common but physical violence was relatively rare. The pages of the Gazette however, gave the impression that Visitors braved the streets in constant fear for their safety, never knowing when an enraged parent would let fly with a stone, an iron, a flowerpot or, as happened on one storied occasion, a dead cat. ${ }^{84}$

For all their lambasting of working-class women and their attempts to define their profession as exclusively male, there was one significant way in which Visitors' preoccupation with a masculinized domestic morality and their focus on the moral 
failings of working-class women encouraged a more prominent public role for women in the discourse of state reform. Embedded in the Visitors' constant criticism of workingclass women's morality and its impact on the home and community was a recognition that, in many respects, women were the true masters of the working-class household. Contradicting the structure of the current laws and the policies of the School Board, SAOs argued that mothers should be held legally responsible for whether children stayed at home, went to work, or attended school. One SAO claimed that mothers often enjoyed enough control over family finances to hide a fine of several shillings from their husbands. ${ }^{85}$ Another article emphasized women's effectiveness as protestors against raising the age limit of mandatory school attendance, a measure that would have further restricted the household income from such children's labor. ${ }^{86}$ It was left to the author of an article entitled "Helps and Hindrances to a Good School Attendance" to explain the results of the discrepancy between the law, which held only men accountable, and the reality of working-class women's domestic authority:

I would just mention a weak spot in the working of the compulsory clauses. I refer to the fact that the whole responsibility for neglect is put on to the father of a family, while a neglectful mother is allowed to go scot free. Every officer knows that in numerous cases the mother is largely responsible for keeping the children from school; and one of the most unpleasant duties that fall to his lot is to visit homes in the evening, to warn fathers as to the attendance of their children. These visits often cause domestic storms which must be seen to be appreciated. ${ }^{87}$

According to these SAOs, working-class mothers held considerable control over their family's finances and their children's behavior. The problem was that mothers used their power in immoral ways to disobey the law and to conceal such disobedience from their unsuspecting husbands. Regardless, for the compulsory attendance system to function effectively, women's legal status vis-à-vis the law would have to change. 
Visitors argued for the legal recognition of what was already a practical reality in working-class homes, namely that a mother's domestic knowledge and authority was at least equal, and in many cases superior, to that of the father. School board cases brought women, as informal advocates of their households, into the local courts by the tens of thousands each year. In the 1890 Edmonton Petty Sessions, which dealt with education cases brought by the Tottenham School Board, although women only made up only $10 \%$ of the legal defendants, they appeared as representatives of their families in more than $80 \%$ of all such cases ${ }^{88}$ Although exact statistics are not available for the London courts, magistrates' accounts and the testimony of Visitors and their Superintendents indicate that the dynamics of such court cases followed a similar pattern in the metropolis, largely because women's ambiguous legal status granted them immunity from the immediate infliction of fines. ${ }^{89}$ Since the father was almost always the legal defendant, it was only from the father that fines could be collected, even when, as was often the case, a woman appeared in court to answer the charges. Throughout the 1870s and 1880s, working-class mothers used their ambiguous legal status to their advantage, publicly defying the authority of the school boards when their cases were brought to court and making the collection of fines an expensive, attenuated, and often futile prospect.

$$
* * *
$$

In their attempts to exclude women from state-sponsored social reform and to define themselves as lower middle class, School Attendance Officers faced a difficult task. To establish their work as most fit for male professionals, SAOs advocated social distance, bureaucratic methods and, when necessary, legal coercion. According to the 
Visitors and their Superintendents, the inherent weakness of women's morality, their inability to serve as legal representatives in the courts, their lack of professionalism, and the ubiquitous physical danger of attendance work made it unsuitable for women. To perform their duties successfully, however, and to counter the hostility of working-class parents, criticism from other members of the educational bureaucracy, and public vilification by opponents of compulsory education, SAOs rapidly integrated the established approach of middle-class women's volunteer philanthropy, which stressed persuasion, knowledge, and personal connection with working-class parents. These latter methods were dependant both upon the "natural" affinities of women and upon the disparity in social status (and therefore moral authority) between middle-class, female reformers and working-class parent. The modest social origins of the men who became SAOs, men who were often drawn from the artisan class, were of little help in this regard.

As a substitute for the qualifications of gender and social position that middleclass women allegedly enjoyed in their dealings with working-class parents, SAOs constructed an ideal of masculinized domestic moral authority. In committee meetings, reports, and the pages of the SAO's professional journal, both the Visitors and their Superintendents asserted that the failures of working-class women's domestic morality and the subsequent degradation of the home could be ameliorated only by the intervention of professional, male reformers. Armed with their Temperance vows, their moral rectitude, and the strength of character that came from their struggles against adversity, SAOs would uplift the working-class home and interrupt the cycle of moral degradation that would otherwise curse all succeeding generations. In doing so, the Visitors aimed to prove not only that this was employment fit for men, but that the men 
who performed it possessed qualities that elevated them, morally and socially, above their working-class charges. State-sponsored social reform, they asserted, required the character, background, and moral authority that only the "right sort of man" possessed. 90

\footnotetext{
${ }^{1}$ School Board Chronicle, 1 July 1871, 200.

${ }^{2}$ Ibid.
}

${ }^{3}$ Chronicle, 24 August, 1872, 36. This wage scale put the average salary of male Visitors well above that of women teachers. At the beginning of the LSB's tenure in London, female teachers were paid between $£ 50-£ 70$ per annum (their male colleagues earned an average of $£ 90-100$ per annum). Chronicle, 23 March $1971,167$.

${ }^{4}$ Thomas Gautrey, "Lux Mihi Laus": School Board Memories (London, 1937), 35. Uniform Enforcement, SBL 129, 31 March 1874, 45.

${ }^{5}$ The Cardiff School Board, for example, after hiring a female officer in 1881, concluded scarcely a year later that "the results did not justify the experiment," and promptly released her. School Attendance Officers Gazette (aka School Attendance Gazette), January 1903, 18.

${ }^{6}$ Seth Koven and Sonya Michel, eds., Mothers of a New World: Maternalist Policies and the Origins of Welfare States (London New York: Routledge, 1993), 2.

${ }^{7}$ Dina Copelman, London's Women Teachers: Gender, Class, and Feminism 1870-1930 (London and New York: Routledge, 1996); Susan Pennybacker, A Vision for London 1889-1914: Labour, Everyday Life, and the LCC Experiment (London and New York: Routledge, 1995).

${ }^{8}$ Joyce Goodman and Cynthia Harrop, eds., Women, Educational Policy-Making and Administration in England: Authoritative Women since 1880 (London and New York: Routledge, 2000) and Jane Martin, Women and the Politics of Schooling in Victorian and Edwardian England (London and New York: Leicester University Press, 1999). 
${ }^{9}$ In order to qualify for hiring, candidates had to take a competitive examination in math, writing, and clerical skills. Rosemary O'Day and David Englander, Mr. Charles Booth's Inquiry: Life and Labour of the People of London Reconsidered (London: Hambledon, 1993), 43.

${ }^{10}$ Although Victorian philanthropic organizations such as the Society for Relief of Distress (f. 1860) and the Charity Organization Society (f. 1869) were sometimes managed by men, the ranks of "visitors" who performed their daily work were overwhelmingly female - so much so that, by the early 1880 s, the written instructions of the COS used the female pronoun exclusively when describing their work. F.K. Prochaska, Women and Philanthropy in Nineteenth-Century England (Oxford: Clarendon Press, 1980), 108-111.

${ }^{11}$ David Lockwood, The Blackcoated Worker: A Study in Class Consciousness (London, 1966; rev. ed., Oxford: Oxford University Press 1989); Geoffrey Crossick, ed., The Lower Middle Class in Britain, 18701914 (New York and Basingstoke: Palgrave Macmillan, 1977); Gregory Anderson, Victorian Clerks (Manchester: Manchester University Press, 1976), and Pennybacker, A Vision for London.

${ }^{12}$ A. James Hammerton, "Pooterism or Partnership? Marriage and Masculine Identity in the Lower Middle Class, 1870-1920," Journal of British Studies 38, no. 3 (July 1999), 293-294.

${ }^{13}$ Gazette, Sept. 1901, 198.

${ }^{14}$ Women comprised a very small minority of the London School Board membership and were particularly underrepresented in the committee that dealt with compulsory attendance. Annual Reports for the School Board for London, 1891 (LMA).

${ }^{15}$ Minutes of Evidence Taken Before the Bye-Laws Committee With Reference to the Uniform Enforcement of the Bye-Laws in the Metropolis (hereafter Uniform Enforcement), 31 March 1874, 45, SBL 129, Records of the London School Board, 45[London Metropolitan Archives].

${ }^{16}$ Ibid.

${ }^{17}$ Ibid.

${ }^{18}$ Goodman in Goodman \& Harrop, Educational Policy-making, 59.

${ }^{19}$ Seth Koven, "Borderlands: Women, Voluntary Action, and Child Welfare in Britain, 1840-1914," in Koven \& Michel, Mothers of a New World, 106.

${ }^{20}$ Martha Vicinus, Independent Women: Work and Community for Single Women 1850-1920 (Chicago: University of Chicago Press, 1985), 22 and Ellen Ross, Love and Toil: Oxford University Press, ch. 1. 
${ }^{21}$ Koven, "Borderlands," 2.

${ }^{22}$ Ibid., 3. Ross, Love and Toil, 18-21, George Behlmer, Friends of the Family: the English Home and its Guardians (Stanford: Stanford University Press, 1998), 60-61.

${ }^{23}$ Vicinus, Independent Women, 212.

${ }^{24}$ Koven, "Borderlands," 103.

${ }^{25}$ Uniform Enforcement, 45; Report of the Special Sub-Committee of the Bye-Laws Committee [of the LSB] on the Administration of the Bye-Laws, 1891, 122-129, SBL 1407 (hereafter RSSC).

${ }^{26} \mathrm{RSSC}, 96,92$.

${ }^{27}$ Gazette, April 1900, 9.

${ }^{28}$ Ibid.

${ }^{29}$ Gazette, June 1902, 105 and Gazette, July 1900, 62.

${ }^{30}$ Judith Walkowitz, City of Dreadful Delight: Narratives of Sexual Danger in Late-Victorian London (Chicago, 1992), 34.

${ }^{31}$ Vicinus, Independent Women: Work, 217; Behlmer, Friends of the Family, 35.

${ }^{32}$ Goodman in Goodman and Harrop, Educational Policy-Making, 61; Behlmer, Friends of the Family, 38; and Lynn Hollen Lees, The Solidarities of Strangers: the English Poor Laws and the People (Cambridge: Cambridge University Press, 1998) 271.

${ }^{33}$ Koven \& Michel, Mothers of a New World, introduction, 9.

${ }^{34}$ Behlmer, Friends of the Family, 39. By the mid-1880s, the Visitors were familiar figures in London's working-class neighborhoods and this familiarity allowed them an unprecedented (though not unlimited) level of interaction with parents.

${ }^{35}$ Behlmer, Friends of the Family, 31.

${ }^{36}$ There is a rich literature on the topic of respectability as both an observed quality and a performed identity. See Thomas Lacquer, Religion and Respectability: Sunday Schools and Working-Class Culture, 1780-1850 (New Haven: Yale University Press, 1976); Ellen Ross, "Not the Sort that Would Sit on the Doorstep: Respectability in Pre-World War 1 London," International Labour and Working-Class History 27 (Spring, 1985); Patrick Joyce, Visions of the People: Industrial England and the Question of Class, 
1840-1914 (Cambridge: Cambridge University Press, 1997); and Peter Bailey, Popular Culture and Performance in the Victorian City (Cambridge: Cambridge University Press, 1998).

${ }^{37}$ Walkowitz, City of Dreadful Delight, 34-35.

${ }^{38}$ Life and Labour of the People of London, The Charles Booth Collection, 1885-1905, pt. 3: The Poverty

Series, School Board Inquiry and House to House Visits, Group B, School Board Visitors' Notebooks

(British Library of Political and Economic Science, London and Emory University Library, Atlanta, GA)

[Hereafter Booth Collection].

${ }^{39}$ Anna Davin, Growing Up Poor: Home, School, and Street in London, 1870-1914 (London: Rivers Oram, 1996), 134.

${ }^{40}$ Ross, "Not the Sort," 48.

${ }^{41}$ Koven, "Borderlands," 99.

${ }^{42}$ Behlmer, Friends of the Family, 39-40.

${ }^{43}$ Ibid., 56-57

${ }^{44}$ Gareth Stedman Jones, Outcast London: A Study in the Relationship Between Classes in Victorian Society (Oxford: Oxford University Press, 1971), 148.

${ }^{45}$ Judith Walkowitz argues that establishing "psychological oppositions that distinguished the Self from the low-Other," was a common dynamic among middle-class, male "urban explorers" such as Engels, Mayhew, Greenwood, Sims, and Charles Booth. Walkowitz, City of Dreadful Delight, 32-33.

${ }^{46}$ Behlmer, Friends of the Family, 98.

${ }^{47}$ Walkowitz, City of Dreadful Delight, 34 and Albert Fried and Richard Elman, eds., Charles Booth's

London (New York: Pantheon, 1968), 4

${ }^{48}$ Booth in Reid and Elman, Charles Booth's London, 292-3.

${ }^{49}$ Ibid.

${ }^{50}$ O'Day and Englander, Charles Booth's Inquiry, 51.

${ }^{51}$ Walkowitz, City of Dreadful Delight, 31.

${ }^{52}$ Booth in Reid and Elman, Charles Booth's London, 332.

${ }^{53}$ Ibid.

${ }^{54} \mathrm{RSSC}, 126$. 
${ }^{55}$ David Rubinstein, School Attendance in London, 1870-1904: A Social History (New York and Hull: Hull University Press, 1969), 95-97

${ }^{56}$ Gazette, March 1901, 197, Aug. 1902, 41.

${ }^{57}$ Gazette, June 1901, 253;

${ }^{58}$ Behlmer, Friends of the Family, ch. 1; Prochaska, Women and Philanthropy, ch. 4; and Ross, Love and Toil, ch. 1 .

${ }^{59}$ Gazette, April 1900, 5.

${ }^{60}$ Gazette, April 1900, 6.

${ }^{61}$ Gazette, July 1902, 125.

${ }^{62}$ See note \#17.

${ }^{63}$ Crossick, The Lower Middle Class, 28.

${ }^{64}$ Gazette, June 1901, 253.

${ }^{65}$ Gazette, Dec. 1902, 225.

${ }^{66}$ According to the article, Salter was no. 15 on the rolls of the Society.

${ }^{67}$ Gazette, August 1902, 141.

${ }^{68}$ Gazette, July 1902, 121.

${ }^{69}$ Gazette, March 1901, 197 and May 1902, 81.

${ }^{70}$ Gazette, July 1902, 121.

${ }^{71}$ Gazette, Sept. 1903, 145.

${ }^{72}$ Gazette, Sept. 1901, 217.

${ }^{73}$ Ibid.

${ }^{74}$ Gazette, March 1901, 197.

${ }^{75}$ Gazette, March 1901, 198.

${ }^{76}$ Gazette, Sept. 1903, 145.

${ }^{77}$ For the prevalence of this argument among volunteer "visitors," see Behlmer, Friends of the Family, ch. 1.

${ }^{78}$ Anon., Compulsory Eduction as Opposed to the Liberty of the Citizen (London, 1875), 7 and Behlmer, Friends of the Family, 22-24. 
${ }^{79}$ Ernest Pomeroy, The Education Tyranny: The Education System Examined and Exposed, Together with Practical Aids for Persecuted Parents (London, 1909), 65.

${ }^{80}$ Gazette, October, 1901, 349.

${ }^{81}$ Booth Collection, B39: Mr. Bruce, Shoreditch [no date given], 1887.

${ }^{82}$ Gautrey, Lux Mihi Laus, 35.

${ }^{83}$ Leeds Daily News excerpted in the Gazette, May 1903, 98.

${ }^{84}$ First reported in Gautrey, Lux Mihi Laus, 35.

${ }^{85}$ Gazette, July 1903, 135.

${ }^{86}$ Gazette, March 1902, 52.

${ }^{87}$ Gazette, January, 1902, 5.

${ }^{88}$ Edmonton Petty Sessions, 1890, PS.E/E3/14-15 [London Metropolitan Archives].

${ }^{89}$ Uniform Enforcement, examination of W. Hetherington, Superintendent of Visitors for Hackney, 21

April 1874, p. 24; Report of the Departmental Committee Appointed by the Secretary of State to Inquire into the Jurisdiction of the Metropolitan Police Court Magistrates and County Justices Respectively in the Metropolitan Police Court District, PP 1900 xl, testimony of John Rose, Magistrate of the West London Police Court, 7 June 1899, 747 [The National Archives].

${ }^{90}$ Uniform Enforcement, 45. 